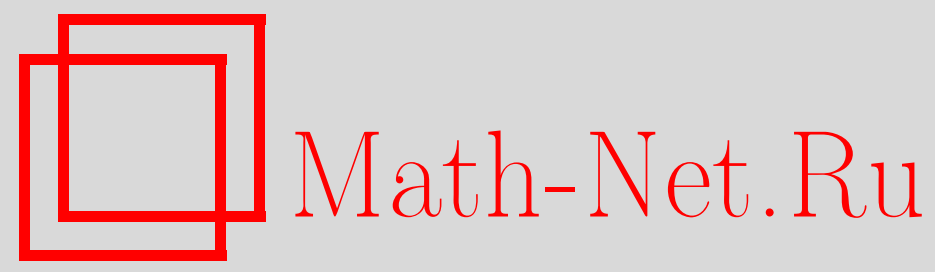

А. С. Кузьмин, Информационное сообщение о мини-симпозиуме CTCrypt-2014, Матем. вопр. криптогр., 2015, том 6, выпуск 2, 5

DOI: https://doi.org/10.4213/mvk139

Использование Общероссийского математического портала Math-Net.Ru подразумевает, что вы прочитали и согласны с пользовательским соглашением

http://www . mathnet.ru/rus/agreement

Параметры загрузки:

IP: 54.198 .55 .26

26 апреля 2023 г., 13:07:20

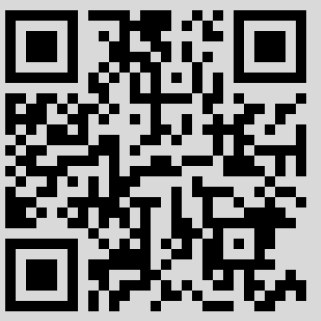




\section{Информационное сообщение о мини-симпозиуме CTCrypt-2014}

В данном номере журнала публикуются математические и криптографические статьи, содержание которых составило основу докладов третьего мини-симпозиума «Современные тенденции в криптографии» (CTCrypt2014), проходившего в г. Москве с 5 по 6 июня 2014 года. В докладах обсуждались теоретические и практические проблемы современной криптографии. Значительная часть докладов мини-симпозиума была посвящена исследованиям принятых в 2012 году национальных стандартов электронной цифровой подписи и функций хэширования, а также предполагаемого к стандартизации нового алгоритма блочного шифрования. В соответствии с правилами мини-симпозиума бо́льшая часть статей публикуется на английском языке с аннотациями на русском языке.

Сопредседатель Оргкомитета мини-симпозиума А. С. Кузьмин 